\title{
ATONEMENT AND THE CRY OF DERELICTION FROM THE CROSS
}

\section{ELEONORE STUMP}

\author{
Saint Louis University
}

\begin{abstract}
Any interpretation of the doctrine of the atonement has to take account of relevant biblical texts. Among these texts, one that has been the most difficult to interpret is that describing the cry of dereliction from the cross. According to the Gospels of Mathew and Mark, on the cross Jesus cries, "My God, my God, why have you forsaken me?" In this paper, I give a philosophical analysis of the options for understanding the cry of dereliction, interpreted within the constraints of orthodox Christian theology; and I show the suggestiveness of this analysis for interpretations of the doctrine of the atonement.
\end{abstract}

\section{INTRODUCTION}

Any interpretation of the doctrine of the atonement has to take account of those biblical texts traditionally taken to be foundational narratives for the doctrine. Among these texts, one of the narratives that has been the most difficult to interpret is the story describing what is commonly called 'the cry of dereliction from the Cross'. According to the Gospels of both Mathew and Mark, among the things Jesus says on the Cross is "My God, my God, why have you forsaken me?"

There are so many things puzzling about this line attributed to Jesus that it is hard to know how to spell them all out. Furthermore, there is a rich biblical context for the line in other parts of the narrative in the Gospels, as well as in various places in the Hebrew Bible, including the Psalms and prophets. Here I will leave all of this to one side, helpful and important though it is. I have learned from consulting or considering it; but in this short paper, in the interest of focusing on just one set of 
problems raised by the story of the cry of dereliction, I will concentrate only on this one line, the cry of dereliction itself. In addition, I will omit consideration of virtually all commentary on this line in the history of interpretation of the Gospels. My purpose here is not historical scholarship on the line but philosophical analysis of it. If the cry of dereliction is to be interpreted within the constraints of orthodox Christian theology, with the traditional assignment of attributes both to God and to Christ, philosophically considered, how is it possible to make sense of it?

\section{UNION: CLOSENESS AND PSYCHIC INTEGRATION}

We can begin by thinking in general about closeness between persons. If distance between persons is part of the story of the cry of dereliction, then what is closeness between persons? For that matter, what is union? Elsewhere I have explored these questions in detail in connection with the account of love given by Thomas Aquinas; here I can only summarize briefly the central points of that discussion. ${ }^{1}$

On Aquinas's account of love, love consists in the interaction of two mutually governing desires, one for the good of the beloved and one for union with the beloved.

Closeness is necessary for the union sought in love. It requires an ability and a willingness on the part of each person in the relationship to share herself, her thoughts and feelings, with the other. But this ability and willingness to share oneself in turn require psychic integration. That is because internal division in the psyche makes a person divided against herself in will or self-deceived in mind or both. Someone who is internally divided against herself in these ways is not united with herself and therefore cannot be united with anyone else either. She will be unable or unwilling to share at least certain parts of herself with anyone else, either because she doesn't really know herself or because she doesn't really want to want something that with another part of her divided self she wants or both.

On an optimistic view of human beings, it is not possible for a person to be internally integrated in moral evil. No one is so evil that there is not some part of his mind and will that retains some hold on the good. Given this view, it follows that all moral wrongdoing fragments a psyche. Since

\footnotetext{
${ }^{1}$ See my Wandering in Darkness, (Oxford: Oxford University Press, 2010), especially chapters 6 and 7 .
} 
fragmentation in psyche diminishes a person's ability to share himself, it also is an impediment to closeness and union. Closeness and union therefore require integration around the good.

On Christian views, the ultimate good for any human person is union with God. Consequently, for God, the two desires of love collapse into one; they come to a desire for union with the beloved. Given the doctrine that God is perfectly loving and loves every person that he has made, it follows that God also always has a desire for union with every person.

\section{UNION: CLOSENESS AND SHARED ATTENTION}

Given these views of love and closeness, it is clear that one obstacle to closeness between a human person and God will come from internal fragmentation in a human being. A person's moral wrongdoing can leave him divided against himself, in a state that wards off closeness with others, including God. Such inner fragmentation is therefore sufficient to undermine or obviate union between persons.

But more than closeness is needed for union. For union itself, significant personal presence is required as well; and significant personal presence includes shared attention. Where shared attention is missing, union is precluded too.

It is difficult to define shared attention, but easy to illustrate it. When a mother looks intently into the eyes of her baby who is also looking intently into hers, there is a kind of shared attention between them. Each of them, mother and baby, is aware of the other and of the other's awareness of her and of the other's awareness of her awareness of the other, and so on. There is something iterative about shared attention.

When there is shared attention between two persons who are already mutually close, then the shared attention between them results in significant personal presence of each to the other and thereby produces union, of one sort or another. By the same token, the absence of such shared attention is an impediment to union. Even between persons who are mutually close, distance can be introduced and union can be warded off by a lack of shared attention.

For union between two persons, then, it has to be the case that each of them is dispositionally close to the other and occurrently sharing attention 
with the other. Both of these conditions are necessary for union, ${ }^{2}$ and the absence of either of them is sufficient for distance between persons. For distance, it is sufficient that one of the persons in the relation lacks closeness or fails to have shared attention with the other.

\section{DISTANCE BETWEEN PERSONS AND THE CRY OF DERELICTION}

Given these reflections on closeness and distance between persons, there are fundamentally three possibilities each of which would be sufficient to account for Christ's experience of distance from God.

First, it could be that

(1) something about God prevents closeness between God and Christ. On this possibility, God fails to be close to Christ, at least at the time of the cry; and it is God's doing that he is not close to Christ.

Second, it could be that

(2) something about Christ prevents closeness between God and Christ. On this possibility, the distance between God and Christ has its source in Christ, not God. Although God has the desires of love for Christ, Christ fails to be close to God, at least at the time of the cry; and it is Christ's doing that there is this lack of closeness.

Third, it could be that

(3) shared attention between God and Christ is hindered.

On this possibility, there is distance between God and Christ because one or the other of them lacks the occurrent condition of sharing attention with the other. In principle, this absence of shared attention is possible even if, at that time, God and Christ each have the dispositions that make for mutual closeness.

This third possibility itself admits of further sub-division, because the responsibility for the lack of shared attention can be assigned to either (or both) of the persons in the relationship. In the case of God and Christ, either

(3a) something about God hinders shared attention between him and Christ

or

(3b) something about Christ hinders shared attention between him and God.

\footnotetext{
${ }^{2}$ They might also be sufficient for union, but in my extensive discussion of this issue in Wandering in Darkness, chapter 6, I did not argue for this stronger conclusion because it is not necessary for my purposes.
} 
Someone might object that (3b) is not a real possibility, because on this possibility Christ turns his face away from God, as it were. But no one who turned his face away from someone else, the putative objector supposes, could experience that other as having forsaken him.

But this is a mistaken supposition on the objector's part. A person in great psychological or physical pain can experience as absent even those gathered around him in love to care for him. In The Lord of the Rings, Tolkien's description of Frodo's psychic state after he is wounded by the Black Riders makes the point in a sensitive and evocative manner. Something about that wound causes Frodo to be intensely aware of the minds of the Black Riders and to find the rest of the world fading or invisible to his view. In the anguish he experiences then, Frodo feels very lost and alone with the Black Riders. When he finally comes to himself again, he is surprised to find that his friends are around him and have been the whole time.

It was Frodo who in his suffering lost the ability to share attention with his friends; but, in his experience, they had disappeared from him. Anyone who has soothed someone in great pain by saying, "It's all right! It's all right! I'm here!" understands the insightful accuracy of Tolkien's story in these scenes depicting Frodo.

Finally, (3b) itself admits of a yet further division, because it is clear that the obstacle in Christ to the sharing of attention with God could be either (3b1) a function of states of intellect and will in Christ or (3b2) a result of something in Christ other than beliefs and desires of his.

These, then, seem to be the possibilities for explaining distance between God and Christ at the time of the cry of dereliction.

\section{THE POSSIBILITIES}

On possibility (1), at least at the time of the cry of dereliction, for one reason or another, God does not want to be close to Christ and so lacks a desire of love for Christ. In this case, Christ experiences God as distant from him because God really is not close to Christ, however much Christ might be willing to be close to God.

Put this way, however, this possibility is clearly ruled out by the divine attribute of love. God always has the desires of love for every person. God may fail to be united with a person; but if he is, it will be because that other person presents an obstacle to union with God, not because God does not have a desire for union with him. And so, as an explanation 
for Christ's experience of distance between him and God, possibility (1) is excluded by the doctrine that God is perfectly loving. ${ }^{3}$

On possibility (2), at least at the time of the cry of dereliction, closeness between God and Christ is lacking because something in Christ blocks such closeness. However much Christ may want closeness with God, something in Christ turns away from it as well. To the extent that it does, in however double-minded a way, one of the desires of love for God - the desire for union - is diminished or over-ridden in Christ.

Manifestly, however, lacking closeness to God for this sort of reason is a morally bad state in the person who turns away from God. But it is part of orthodox Christian doctrine that Christ is never in a morally bad state. Consequently, it is not possible to attribute to Christ the turning away from closeness with God that possibility (2) would assign him. And so possibility (2) can be excluded as well.

On possibility (3), at least for the time of the cry of dereliction, distance between God and Christ is introduced by a lack of shared attention between them. Even if there is mutual closeness between God and Christ in general, one of them is not present to the other because shared attention between them is hindered at that time.

On possibility (3a), God is responsible for this lack of shared attention. But God can be responsible for it only if God has decided for some reason to block his sharing attention with Christ, since nothing external to God can block God's willingness to share attention with anyone.

There are very few attempts to explain why a good and loving God would turn his face away from Christ. The best is probably that given by Calvin. Calvin thinks that God turns away from Christ in order to let Christ feel himself lost, like one of the damned in hell. Since damnation

\footnotetext{
${ }^{3}$ This conclusion needs some nuancing, of course. A wife whose husband is unfaithful may move out of their home, in the hope that her absence will cause him to reconsider his behaviour. Similarly, when human persons turn away from God, it is possible for God to withdraw from them as a means to prompt them to be willing to return to him. In such a case, although God is absent, his absence is prompted by the lack of the desires of love for him on the part of human persons. A case of this sort is at issue in this line from Isaiah: "your evildoings have separated you from your God, and your sins have hidden his face from you." (59:2) In this sort of case, God withdraws from human persons, but it remains true that God has the desires of love for the persons from whom he withdraws. His withdrawal is a response to their withdrawal from him. Since this nuancing in fact attributes ultimate responsibility for the distance between God and human persons to the human persons, then, it can safely be assimilated to possibility (2).
} 
in hell is part of the penalty for human sin, on Calvin's view God lets Christ share in this part of the human penalty too. ${ }^{4}$

On Calvin's sort of explanation, God brings it about that Christ experiences as real what is in fact not real, namely, Christ's rejection and damnation by God. To this extent, however, God deceives Christ. Now it may be compatible with goodness to deceive a morally bad person, as when one lies to the Gestapo to protect the Jewish children in the house. But it is hard to see how it could be compatible with God's goodness to deceive a perfectly good person.

It is true that Calvin supposes God has a good goal for bringing about this experience for Christ, namely, that the suffering the experience entails is somehow necessary for the salvation Christ achieves for human beings. But, as even Calvin must acknowledge, a perfectly good God would not chose means incompatible with his love and goodness to bring about a good goal. If Calvin himself did not accept this very claim, his explanation of the need for Christ's suffering in hell would itself fail. If one did not accept this claim, one could simply reject Anselmian intuitions and attribute to God the salvation of human beings without anyone's bearing the human penalty for sin.

In my view, for these reasons, possibility (3a) can be excluded, too.

We are now apparently left with the two versions of possibility (3b), namely, that (3b1) some state of Christ's intellect and/or will or else (3b2) something in Christ other than his beliefs and desires is responsible for the lack of shared attention between God and Christ. In my view, we can quickly rule out (3b1), for just the reasons canvassed above in connection with possibility (2). If there were nothing external to him constraining him to do so, a perfectly good person would not think it was good or appropriate to turn his face away from a perfectly good God with whom he has mutual closeness, and he would not want to do so either. In no way would such a person want to turn his face from God's.

But (3b2) does not seem promising either. We could try making sense of this possibility by pointing to the great pain caused by crucifixion. But there seems to be an a fortiori argument against this explanation. Since so many others in Christian history seem to have experienced pain at least as great as crucifixion without losing their ability to stay connected

${ }^{4}$ See, for example, John Calvin, The Institutes of the Christian Religion, tr. Henry Beveridge, vol. 1, [Grand Rapids, MI: Eerdmans, 1970], Book II, Chap.xvi, pp. 443-444. 
to God, it seems implausible to suppose that physical pain alone would have such an effect on Christ. ${ }^{5}$

\section{MINDREADING}

At this point, it may seem as if we have excluded all the possibilities for making sense of the cry of dereliction. But, in my view, there is in fact one possibility left which is worth exploring in this connection. To see it, we have to understand something about mind-reading, as it often called in contemporary scientific literature. ${ }^{6}$ In mind-reading, one person knows intuitively something about what another person is doing and with what motive and emotion he is doing it. Contemporary neurobiologists believe that this kind of knowledge of persons is subserved by a neurologically distinct system, currently thought to be the mirror neuron system. Mirror neurons fire both when a person does a particular kind of action and also when he sees someone else performing such an action.

The kind of knowledge given by the mirror neuron system is not a kind of knowledge that. Rather it is a matter of knowing from one's own internal state what someone else is doing and feeling. With regard to knowledge of the emotions of another person, for example, researchers hold that "[because of the mirror neuron system,] observing another person experiencing emotion can ... result in the direct mapping of that sensory information onto the motor structures that would produce the experience of that emotion in the observer.... [in that case] recognition [of the emotion of the other] is firsthand because the mirror mechanism elicits the same emotional state in the observer."

The point is easier to appreciate if we think of empathy, which is currently thought to be subserved by the mirror neuron system, too.

\footnotetext{
${ }^{5}$ John Calvin says, "let the pious reader consider how far it is honourable to Christ to make him more effeminate and timid than the generality of men. Robbers and other malefactors contumaciously hasten to death, many men magnanimously despise it, others meet it calmly. If the Son of God was amazed and terror-struck at the prospect of it, where was his firmness or magnanimity?" [The Institutes of the Christian Religion, tr. Henry Beveridge, vol. 1, (Grand Rapids, MI: Eerdmans, 1970), Book II, Chap.xvi, p. 445.] Calvin is speaking of Christ's suffering in the garden before his passion, but the point applies as well to Christ's suffering on the cross.

${ }^{6}$ For more discussion of mind-reading, see chapter 4 of my Wandering in Darkness, (Oxford: Oxford University Press, 2010). In this paper, I am developing and extending some of my remarks there.
}

${ }^{7}$ Rizzolatti et al., "Mirrors in the Mind”, Scientific American, 295/5 (Nov. 2006), 60. 
One person Paula empathizes with an emotion in another person Jerome because the mirror neuron system produces in her an emotional state like the emotion Jerome is experiencing, but taken off-line, as it were. In empathy with Jerome's suffering physical pain, for example, Paula will feel something of Jerome's pain, but she will feel it as Jerome's pain, not as hers. Paula doesn't actually suffer physical pain herself, but in empathy with Jerome the feeling Paula has is a feeling that is in some respects like the suffering of physical pain.

And, in general, in mind-reading Jerome, Paula will know what it feels like to do the action Jerome is doing, what it feels like to have the intention Jerome has in doing this action, and what it feels like to have the emotion Jerome has while doing this action. In all these cases, Paula will know these things through having herself some simulacrum of the mental state in Jerome. Something of Jerome's mental state will be in Paula, but off-line.

In this one respect, mind-reading is like dreaming. If Paula dreams that she is running, her brain will fire those motor programs it would fire if she were in fact running, but it fires them off-line, so that there is no muscle movement in Paula's legs even while her brain is running the motor programs usually used to produce that muscle movement. In the same way, through the mirror neuron system, Paula can have a mental state that mimics Jerome's mental state, but without herself actually being in that very mental state.

In such a case, the mental state in Paula really is Paula's. But, unlike the mental state of Jerome's that Paula is sharing, Paula's mental state is not connected in the usual way to other mental states of Paula's. Among other things, it is not accompanied by the states of will and intellect that mental state has in Jerome. For example, in empathy with Jerome when he has cut his finger badly, Paula may mind-read Jerome's feeling of pain. In that case, Paula will feel some kind of pain too, and the pain will really be Paula's, even if it is only empathic rather than physical pain. But Paula will not believe that it is her finger that is cut, and she will not want medical attention for her finger. So she will not have the states of intellect or will that she would have if she really had those very feelings of pain in her finger that Jerome has.

In the case of dreamed motion, the brain's motor programs for running are off-line in that while they are firing, they are disconnected from the muscles in the legs and so don't produce actual running. In the case of mind-reading, the brain's mirror neuron system runs the programs it 
would run if Paula were doing what Jerome is doing, but it runs them disconnected from those states of will and intellect Paula would have if in fact she were doing those acts. In this way, Paula shares in Jerome's mental states but without having them as Jerome has them, in virtue of having her own states of intellect and will, not Jerome's, even while she feels what she would feel if she were doing what Jerome is doing.

\section{MINDREADING AND MORAL EVIL}

It is worth reflecting in this connection that mind-reading between two people Paula and Jerome can also occur when Jerome is engaged in doing actions that are evil or vile or morally repulsive in some other way. That this is so helps explain why watching such actions, in real life or in videos, for example, is so distressing to most people. Graphic videos of violence or abuse are disturbing because such scenes also prompt mindreading in the viewer. The mirror neuron system gives the viewer some (no doubt limited) sense of what it feels like to do such things. And feeling what it feels like to do such things can be very troubling if the things in question are deeply revulsive to one's sensibilities.

To see better why this is so, it helps to understand that serious moral wrongdoing leaves its effects on parts of the wrongdoer's psyche other than just his intellect and will. There are cognitive faculties besides intellect and will, and wrongdoing can leave them morally worse, too. For example, most people cannot simulate the mind of a person who rapes a child; and we give expression to that incapacity by saying things like "I can't imagine how a person can do a thing like that!". But the rapist himself does understand how a person can do a thing like that. He knows what it feels like to do an evil of that sort and, what is worse, what it feels like to want to do an act of that sort.

That a person is morally the worse for knowing what such things feel like is clear, although the moral flaw here is not a matter of the agent's having morally wrong desires or morally wrong beliefs about what is good. That is why such a condition is not by itself culpable or worthy of punishment, but there is something morally lamentable about it all the same. ${ }^{8}$ Even apart from morally deplorable states of intellect and will,

\footnotetext{
${ }^{8}$ Not everything that is morally deplorable is also culpable. That is at least in part because it is possible for a person to be in a morally bad condition without being responsible for being in that condition and therefore worthy of blame for it. A man
} 
there is a kind of moral flabbiness in the psyche of a person who has engaged in serious evil, and that moral slackness causes others around him to react with revulsion to him even when there is no worry about continued evil on his part.

An extreme case of such moral plasticity can be found in the psychic state of Rudolf Hess at the end of the war. The psychiatrists who examined Hess at Nuremberg testified both to his self-serving cunning and to his "great instability"; and Major Sheppard said of Hess, "I believe by the nature of his make-up, which reflects cruelty, bestiality, deceit, conceit, arrogance, and a yellow streak, that he has lost his soul and has willingly permitted himself to become plastic in the hands of a more powerful and compelling personality." ${ }^{10}$ The malleability to which Sheppard called attention was itself morally revulsive to those around Hess.

Repentance can reshape previously bad states of intellect and will, but by itself it cannot take away totally the revulsive features in the psyche such as those Sheppard pointed to in Hess. Aquinas called such psychic leftovers of serious evil 'a stain on the soul', and the metaphor is helpful. Something that was lovely in Hess before he participated in the Nazi horrors was lost by his evil actions, and repentance is not by itself sufficient to restore him to the moral fitness he had before his evil acts. ${ }^{11}$

That this is so helps to explain why even if Hess had been completely repentant after the war, people would still have wanted to be at some distance from him. Hardly anyone would have been willing to invite even a totally repentant Hess to dinner if there were children at home.

in an isolated area in some much earlier time in human history might have been completely persuaded that wife-beating in certain circumstances was obligatory for him. When he beat his wife in those circumstances, his psychic state would have been morally deplorable. But most people would hesitate to consider him culpable or worthy of punishment for that act, because we would suppose that he is not responsible for his morally bad psychic condition.

${ }^{9}$ See Interrogations: The Nazi Elite in Allied Hands, 1945, ed. Richard Overy (New York: Viking Penguin, 2001), p. 419.

${ }^{10}$ Overy, 2001, p. 401.

${ }^{11}$ This is not to say that nothing could take away this stain. In my paper, "Personal Relations and Moral Residue" [in History of the Human Sciences: Theorizing from the Holocaust: What is to be Learned?, Paul Roth \& Mark S. Peacock (eds.), Vol. 17 No 2/3 (August 2004), pp. 33-57], I discuss and argue for a certain kind of remedy for the stain, based on Aquinas's particular understanding of the notion of satisfaction. Satisfaction is NOT required for forgiveness. Its effect is to change comparative standing and relational attributes for the person making the satisfaction. 
In complete repentance, Hess would have had the states of will and intellect which a morally good person has. But he still would have had the leftover stain on the soul, as Aquinas puts it, and those around him would have shrunk from him in consequence. Even if there is nothing worthy of blame or punishment in a thoroughly repentant wrong-doer, the leftover stain on the soul leaves him in a morally worse condition than he was in before he did the evil in question.

Many things go into this stain, but one central element of it is certainly the knowledge of what it is like to do the evil things Hess did. Mind-reading transfers some simulacrum of this knowledge. Seeing a person engaged in a seriously evil act such as the rape of a child, in real life or on videos, is disturbing because the mind-reading capacities of the mirror neuron system are engaged in such cases too. Because mind-reading introduces into the viewer a sense of what it feels like to do the evil acts being seen, and to want to do them, mind-reading the mental states of someone engaged in moral monstrosity will produce feelings that are horrible to ordinarily decent people.

If Paula views and mind-reads Jerome while he is engaged in morally evil acts, then Paula will gain something like a simulacrum of the moral slackness in Jerome even while she lacks those states of intellect and will which enabled Jerome actually to engage in the evil acts. The as-itwere slackness in Paula's psyche is not itself a moral evil on Paula's part, just because Paula lacks the states of will and intellect Jerome has while he does the evil acts in question. Because the mirror neuron system enables Paula to share something of Jerome's mental states off-line, as it were, Paula does not contract the moral evil Jerome has. Paula gains a simulacrum of the stain on Jerome's soul; but since Paula gains this imitation stain without any evil acts of her own intellect or will, she is not blameworthy or otherwise culpable for having it. She has only an off-line re-presentation of Jerome's psychic states, not the real thing.

On the other hand, the feeling that Paula has in such cases is real and is her own. For a morally decent person, the psychic states generated by a mind-reading connection with a person engaged in serious evil will produce psychological pain ranging from distress and revulsion to the catastrophically traumatic. When Tolkien's Frodo is connected in a telepathic way with the minds of Mordor's Black Riders, the horror is so traumatic for him that he never recovers from the experience. The 
rest of his life is marked by a periodic recurrence of that experience of horror and its suffering.

Human beings are a highly social species, and the mirror neuron system is part of what enables human beings to function as the social animals they are. Mind-reading connects people into smaller or larger social groups which can function as one because the mind-reading unites them psychically to one extent or another. The great good of this system is highlighted by what happens when it is impaired, as it is in autistic children. But the other side of the coin is that the same system also enables a mind-reading union of sorts between the psyche of a morally decent person and the psyche of an evil person, and a psychic connection of that sort will be an affliction of one sort or another for the morally decent person.

\section{MIND-READING, SHARED ATTENTION, AND CHRIST'S DISTANCE FROM GOD}

Just as great physical pain can hinder or block a person's ability to share attention with another, even if the two of them love each other and are mutually close, so the psychological pain attendant on a mindreading connection with a person engaged in serious evil can have the same effect. If Paula is connected with Jerome in the mind-reading way when Jerome is engaged in serious moral evil, that connection can leave Paula unable to share attention with another person Julia, even if Julia is right there for Paula, present to Paula in every respect except for Paula's inability to find Julia in her pain. When Frodo is in the grip of his mind-reading connection with the Black Riders, the whole world around him dims. His loving friends, deeply concerned for him, caring for him, and present with him, fade for him. In the grip of the telepathic connection to the Black Riders, everything else, even the surrounding inanimate environment, begins to disappear for Frodo. The horror of the minds of the Black Riders fills his whole conscious mind and blocks out everything else, until finally he faints from pain.

And so mind-reading and the connection between persons it effects give us another option for understanding the distance between Christ and God at the time of the cry of dereliction on the cross. The love and goodness of God and the love and goodness of Christ seemed to rule out all the possibilities for explaining that distance, except (3b). 
That possibility assigns responsibility for interrupted shared attention between God and Christ to something having to do with Christ. But it was hard to know how anything having to do with Christ could be responsible for hindering shared attention between Christ and God in a context of mutual love and closeness between them. Morally bad states of intellect and will are ruled out for Christ, and physical pain is insufficient to explain Christ's experience of distance from God too.

But the mind-reading capacities of human beings shows us that, with regard to possibility (3), tertium datur. In principle, Christ can be the source of the blocking of shared attention between Christ and God because of

(3b1) something in Christ's intellect and/or will,

or

(3b2) something external to Christ,

or - as the description of the mind-reading system makes clear -

(3b3) something relational between Christ and other human beings.

It is Christian doctrine that on the cross Christ bore the sins of all human beings. There are, of course, many explanations of this claim. Virtually all of them suppose that in taking on human sin during his crucifixion, nothing about Christ's intellect and will became truly morally evil. On the other hand, most such explanations also suppose that there is some sense in which the evil of human beings became something Christ took into himself.

The mind-reading system provides one interesting explanation for how Christ could take into himself all human sin at once on the cross without having himself any morally evil beliefs or states of will. If on the cross Christ's human psyche is somehow connected with the psyches of every human being, then at one and the same time Christ will mindread the mental states found in all the terribly evil human acts human beings have ever committed. Every vile, shocking, disgusting revulsive evil psychic state accompanying all human evil will also be at once in the psyche of Christ, only off-line. He will have in his psyche the simulacrum of all the stains of all the evil ever thought or done, without having any evil acts of his own. One might say that as the ravages of the crucifixion scar his body, this mind-read evil scars his psyche.

The mind-reading system therefore gives one kind of explanation for Christ's bearing all human sin himself while at the same time remaining without moral evil of his own. 
But the mind-reading system also provides a way in which to understand Christ's experience of distance between himself and God. There is plausibility as well as sensitivity in Tolkien's portrayal of Frodo's mind as so filled with the minds of the Black Riders that all the world around him fades from his view. Overwhelmed by that telepathic connection, Frodo cannot find his friends, even though they are right there by him, filled with love and care for him. Their mutual love and closeness is not diminished, but Frodo cannot access it, because he loses his ability to share attention with his friends while he is suffering the horror of that telepathic connection.

If Tolkien's story seems plausible as regards Frodo, then it does not seem implausible to suppose that an analogous story, mutatis mutandis, could be told about Christ. The suffering of Christ's psychic connection all at once with all the evil mental states of every human evildoer would greatly eclipse any other human psychological suffering. It would dwarf an experience of suffering such as that brought about by Frodo's telepathic connection to the minds of Mordor, no matter how evil those minds are and no matter how terribly traumatic a telepathic union with such a mind would be. Flooded with such a horror, Christ might well lose entirely his ability to connect to the mind of God. For Christ in such a condition, God would be even more inaccessible than Frodo's friends were to him when the Black Riders occupied his mind.

Furthermore, because in his psychic connection with the evil in every human being Christ would also have a simulacrum of the stains on the soul accompanying all that evil, he would feel the moral ugliness of all that evil in himself. In that condition, why wouldn't he cry that God had forsaken him? The ugliness of those stains, even in their off-line or simulated form, is a world away from the beauty of God's goodness; and though the movement creating that distance is Christ's, the experience for him will be God's receding from him. For those on a boat moving out to sea, the shore seems to recede, although it is they who are moving, not the shore. An unwilling passenger on such a boat may well feel his home is leaving him as the shore becomes ever more distant, even while something in his mind also knows that it is he who is moving. In the same way, it is possible for Christ to feel that it is God who has gone from him even while it is the overwhelming of his mind by the connection with the evil in human minds that deprives him of his ability to share attention with God. 


\section{CONCLUSION}

Philosophical reflection on the biblical narrative attributing to Christ the cry of dereliction from the cross gives an interpretation of one part of the atonement, that process whereby something about Christ's passion and death brought about a solution of some sort to the problem of human $\sin$. On this interpretation, in crucifixion, the psyche of Christ was really united with the psyches of all human beings in all their good and also in all their evil. If this union makes the psyches of human beings accessible to Christ, then presumably, since union is a symmetric relation, the same union also makes the psyche of Christ accessible to every human being. Just as it is not hard to see how a deep psychic connection of a mindreading sort with all the evil in every human psyche might be a shattering affliction for Christ, so it is not so hard to see that accessibility to the psyche of Christ might be a great redemptive good for human beings. Wrestling with the story of the cry of dereliction therefore produces some significant insight into the atonement. But, however helpful it is, this insight by itself is hardly a complete interpretation of the doctrine of the atonement. Some of the most important questions about atonement still remain unanswered. What is there about psychic union of this mindreading sort between Christ and human beings that makes it essential to the atonement? And what is there about crucifixion that is essential to this psychic union? Why couldn't the good brought about by atonement be gotten as well without such psychic union and crucifixion as with it?

By itself, this interpretation of the cry of dereliction cannot provide the answers to these questions, but it does help in discerning what directions could profitably be followed in looking for the answers. ${ }^{12}$ It emphasizes the relation, the psychic union, between Christ and human beings as part of the process of the passion itself. And so it also opens the way for a more Trinitarian account of the atonement.

Traditionally, the Holy Spirit has been taken to have an essential role in the process of sanctification, which is one of the ends achieved by the atonement; but it hasn't been clear what the connection is between the passion and death of Christ, on the one hand, and the sanctification brought about by the Holy Spirit, on the other. The interpretation of the cry of dereliction I have argued for is suggestive on this score. On

${ }^{12}$ I am grateful to William Abraham, Paul Griffiths, and audiences at the American Academy of Religion and the University of Notre Dame for helpful comments on an earlier draft of this paper. 
Trinitarian doctrine, the Holy Spirit is united with Christ. And so, if on the cross the mind of Christ is united with all human psyches, then through this union the Holy Spirit is united with them as well. But pursuing a suggestion of this sort requires a book-length project. It is enough for this paper to have shown one way of understanding the cry of dereliction and the suffering that powers its expression. 